\title{
Physiological and biochemical characteristics associated with leaf retention in mulberry (Morus spp.)
} \author{
Nirvan Kumar Das, Partha Dev Ghosh ${ }^{3}$, Kunjupillai Vijayan ${ }^{4}$ \\ ${ }^{1}$ Central Sericultural Research and Training Institute, Mysore, India; \\ ${ }^{2}$ Research Extension Centre, Nabagram, India; \\ ${ }^{3}$ Botany Department, Kalyani University, Kalyani, India; \\ ${ }^{4}$ Central Silk Board, BTM Layout, Bangalore, India. \\ Email: sgdoss@gmail.com
}

Subramaniam Gandhi Doss ${ }^{1}$, Shyama Prasad Chakraborti ${ }^{2}$, Soumen Chattopadhyay,

Received 23 September 2011; revised 30 October 2011; accepted 11 November 2011.

\section{ABSTRACT}

Mulberry leaf production plays a key role in the sustainability of silk industry as the silkworm Bombyx mori can not survive on any other leaf. In fact, silkworm merely acts as an instrument to convert mulberry leaf proteins into the silk proteins. In India, West Bengal is the second highest silk producing state but with varied climatic conditions and suffers to a great extent from non-availability of adequate quantity of quality leaf during the colder months. Delayed sprouting, slow growth rate and higher leaf fall are the major factors contributing this leaf scarcity. To overcome these problems, nine mulberry genotypes, developed through systematic breeding, were tested against the current popular variety for 3 consecutive years taking into account of their performance during the colder months. Annual leaf yield was highest in CT-44 (48 mt/ha/ year) followed by CT-11 (44 mt/ha/year). Leaf senescence was least in CT-44 (9.8\%) followed by CT-11 (16.8\%) while the check variety showed $20 \%$ leaf senescence. Significantly higher values were observed for net photosynthetic rate $\left(P_{n}\right)(14.83 \mu$ mol. $\left.\mathbf{m}^{-2} \cdot \mathbf{s}^{-1}\right)$; physiological water use efficiency (pWUE) (1.16 $\left.8 \mathrm{~mol} \mathrm{CO}, \mathrm{mol}^{-1} \mathrm{H}_{2} \mathrm{O}\right)$; total soluble protein (TSP) $\left(27.87 \mathrm{mg} \cdot \mathrm{g}^{-1} \cdot \mathrm{fw}\right)$; total soluble sugar (TSS) $\left(39.74 \mathrm{mg}^{\cdot} \mathrm{g}^{-1} \mathrm{fw}\right)$; nitrate reductase activity (NRA) (17.78 $8 \mathrm{~mol}$. $\left.\mathrm{NO}_{2} \cdot \mathrm{g}^{-1} \cdot \mathrm{fw}^{\cdot} \mathrm{h}^{-1}\right)$ in CT-44. Correlations of these physiological and biochemical characters with leaf yield and leaf senescence (\%) revealed highly significant positive correlations of leaf yield with $P_{n}(0.536)$, TSP (0.674), NRA (0.610), pWUE (0.433), LAI (0.776) and negative correlations with leaf senescence $(-0.239)$. TSS $(0.292)$ and TSP (0.780) had positive association with NRA. Leaf senescence $(\%)$ had significant negative association with $P_{n}(-0.755)$, TSP $(-0.462)$, NRA $(-0.438)$ and pWUE (-0.359). Path co-efficient analysis revealed the direct effect of $P_{n}(0.218)$, TSP $(0.449)$ and LAI (0.730) on leaf yield. The study, therefore, indicated the possibility of using $P_{n}$, TSP, NRA and LAI for selecting varieties with higher leaf yield with low leaf fall during colder months.

Keywords: Cold Tolerance; Leaf Senescence; Mulberry; Photosynthetic Rate; LAI

\section{INTRODUCTION}

Sericulture is an agro-based industry playing a major role in poverty alleviation by providing employments in the rural areas of India [1]. Sericulture has two components, the mulberry and the silkworm. Availability of mulberry leaf is the key factor that decides the success and sustainability of sericulture. Traditional areas of sericulture, in the state of West Bengal, confine mostly to three big districts namely Murshidabad, Malda and Birbhum due to the congenial climatic conditions prevailing there. Of the five silkworm crops, the high yielding bivoltine hybrids are reared during the autumn to spring period (Oct. - Feb.). This is because during this period, the temperature is very low; hence, farmers can manipulate the temperature by using low cost room heating methods to make the optimal temperature range of $26^{\circ} \mathrm{C}-28^{\circ} \mathrm{C}$. However, during this best period for silkworm rearing, the availability of quality mulberry leaf is heavily reduced due to several characters like delayed sprouting of buds after pruning, slow growth and higher leaf senescence [2]. For instance, the leaf yield of the current popular variety S-1635 showed a reduction of $31 \%$ - 33\% due to leaf senescence [3]. Since the average land holding of the farmers in these traditional areas of sericulture is ca. 0.66 acre [4], the 
reduction in the leaf production seriously hamper their ability to rear ample quantities of silkworm during this period. Thus, it is essential to develop mulberry varieties, which are capable of tolerating the cold and retain more leaves (delayed senescence) to a great extent to maintain normal leaf yield during this period [2].

Efforts to develop cold tolerant crop plants through conventional breeding techniques have not resulted in much success as expected in the beginning due to the complex nature of cold tolerance as cold tolerance is known to be controlled by many different genes and the mechanism of how those genes control cold tolerance is still not clear $[5,6]$. Nonetheless, studies in wheat, rice, barley and other crop plants have thrown light into many aspects of cold hardiness. It has been observed that during cold exposure, plants accumulate several gene products including high and low molecular weight cryoprotectants [7]. Similarly, various tissues in the plant behave differently to the cold. For instance, meristematic cells are less resistant than mature tissues [8]. Seasonal change in cold resistance was also noted in many perennial plants of temperate and subarctic climates $[9,10]$. Likewise, plants of tropical and subtropical areas show detrimental effect of low temperatures above the freezing point, a phenomenon known as 'chilling' [8]. The extent of the damage caused by low temperature depends on many factors, such as its developmental stage, the duration and severity of cold, the rates of cooling etc. It is also noted that during cold exposure, wheat accumulated reducing sugar, free amino acids, and free proteins but showed reduction in respiration [11]. Genotypic differences on response to cold was also noted as the abscisic acid (ABA) content in nine wheat genotypes differing in cold tolerance showed significant variations and the increase in ABA content was in correspondence with the cold tolerant capability of the genotype [12]. The authors referred at reference [13] observed the size of guard cells in the leaf of cold hardy varieties were bigger than that in cold susceptible verities. Number of chloroplasts in the guard cells was higher in cold hardy varieties. Further, it has also been noted that delayed leaf senescence during colder months can reduce the yield loss substantially in many flowering plants [14]. Since leaf senescence in mulberry is depends on different growth attributes which is also in turn influenced by the genetic expression of important physiological and biochemical characters of delayed senescent genotypes, it is essential to identify the crucial physio-biochemical characters that have major contributions to the delayed leaf senescence and ultimately to the leaf yield. Hence, path co-efficient analysis is an indispensable tool to elucidate the direct and indirect relationship among the physiobiochemical characters, leaf senescence and leaf yield.
Keeping these points in view, the current investigation was undertaken to identify important physio-biochemical characters associated with delayed leaf senescence and higher leaf yield in mulberry, which can provide stable leaf yield irrespective of the seasonal changes.

\section{MATERIALS AND METHODS}

Based on its leaving the border lines, data was recorded in 5 crop the available information on important morphological, biochemical, anatomical, reproductive and physiological characteristics of the 162 mulberry accessions present in the germplasm bank of Central Sericultural Research and Training Institute, Berhampore, West Bengal [15-19], 23 potential parents were selected and systematic breeding was effected as described by reference [20]. From the seedling of 3500 seed, 2700 hybrids were transferred to progeny row trial and evaluated for two years for leaf yield and growth parameters (data not shown). Based on the assessment, 210 hybrids selected and evaluated in Primary yield trail under Augmented Randomized design (data not shown). From these, nine genotypes viz., CT-6, CT-9, CT-11, CT-15, CT-44, CT-94, CT-156, CT-185 and CT-210, having delayed leaf senescence, stable growth and leaf yield were selected for detailed evaluation under RBD design in final yield trail. For each of the three replications, 49 clonally raised saplings were planted and all the recommended cultural practices for irrigated plantations were followed [21]. After one year of establishment in the field, data on leaf senescence rate was collected from five randomly selected plants from each replication. Leaf yield was recorded from all planseasons annually for 3 consecutive years. The percentage of senescent leaves was estimated as:

$$
\text { Leaf senescence }(\%)=\frac{L_{y}+L_{a}}{L_{p}+L_{a}+L_{y}} \times 100
$$

Where $L_{y}=$ Number of yellow leaves (Yellowing of the leaf area $>25 \%$ has been considered as senescent leaf); $L_{a}=$ number of leaves absent (fallen) due to senescence (This was obtained by counting the number of nodes without leaves from the bottom of the stem in the experimental plants); $L_{p}=$ number of green leaves present on the stem.

Physiological parameters such as photosynthetic rate and physiological water use efficiency were recorded with the help of a portable photosynthetic meter (LI6200, LI-COR Inc., Lincoln, NE, USA). All measurements were taken between $11.00 \mathrm{am}-12.30 \mathrm{pm}$ to minimize the diurnal variations in chlorophyll titer and photosynthetic rate. At each time of measurement, the $\mathrm{CO}_{2}$ concentration was near ambient (300 - $400 \mu$ moles $\left.\mathrm{l}^{-1}\right)$. 
The net exchange of $\mathrm{CO}_{2}$ between leaf and the atmosphere was measured by monitoring the rate at which the $\mathrm{CO}_{2}$ concentration in the air changed over fairly a short interval of time (10 s - $20 \mathrm{~s})$. The net photosynthetic rate $\left(\mathrm{P}_{\mathrm{n}}\right)\left(\mu\right.$ moles $\left.\mathrm{CO}_{2} \mathrm{~m}^{-2} \cdot \mathrm{s}^{-1}\right)$ was then calculated using that rate of change and some other factors such as the amount of leaf area that was enclosed, the volume of the enclosure, temperature and pressure.

Total soluble sugar (TSS) and total soluble protein (TSP) were estimated following the method described in the references [22,23], respectively. Measurements were taken in a spectrophotometer (Shimadzu A160, Tokyo, Japan) at $650 \mathrm{~nm}$. In vivo nitrate reductase activity was estimated from freshly collected leaf samples following a modified method of $[24,25]$. Statistical analysis of the data was carried out in different software for estimating the significance of variation, correlations and path coefficient analyses of important physio-biochemical characters.

\section{RESULTS}

The nine genotypes showed significant differences in all the parameters used for the study (Tables 1-5). The mean annual leaf yield varied from $32.05 \mathrm{mt} / \mathrm{ha} /$ year in CT-94 to $47.94 \mathrm{mt} / \mathrm{ha} /$ year in CT-44 among the test genotypes. The genotypes CT-11 (43.99 mt/ha/year) and CT-44 (47.94 mt/ha/year) out yielded the check variety S-1635 (40.92 mt/ha/year) by $7.50 \%$ and $17.17 \%$, respectively. The leaf yields in these genotypes were consistently higher in all the five crop seasons (Table 1). During the colder months, November and February the leaf of CT-44 was much higher than any of the other genotypes including the control variety. Among the developed genotypes, the mean annual leaf senescence rate varied from $9.80 \%$ in CT-44 to $17.81 \%$ in CT-185. However, the leaf fall, 20.13\%, in the check variety S1635 was much higher than that in all the test genotypes (Table 2). The physiological and biochemical characters such as $P_{n}$, pWUE, TSS, TSP and NRA were found significantly

Table 1. Leaf yield performance of nine selected delayed senescent mulberry genotypes.

\begin{tabular}{|c|c|c|c|c|c|c|c|}
\hline \multirow{2}{*}{ Genotype } & \multicolumn{5}{|c|}{ Leaf yield (mt/ha/season) } & \multirow{2}{*}{$\begin{array}{c}\text { Total } \\
\text { (mt/ha/year) }\end{array}$} & \multirow{2}{*}{ Yield gain (\%) } \\
\hline & Sept & Nov & Feb. & Apr. & July & & \\
\hline CT-6 & 8.84 & 7.15 & 7.15 & 8.09 & 9.48 & 39.88 & -- \\
\hline CT-9 & 7.03 & 7.45 & 7.45 & 8.03 & 8.44 & 38.00 & -- \\
\hline CT-11 & 8.68 & 7.78 & 7.78 & 8.61 & 10.76 & 43.99 & 7.51 \\
\hline CT-15 & 7.87 & 7.03 & 7.03 & 8.59 & 9.31 & 40.43 & -- \\
\hline CT-44 & 9.67 & 9.19 & 9.19 & 9.56 & 11.59 & 47.94 & 17.17 \\
\hline CT-94 & 6.20 & 5.56 & 5.56 & 7.12 & 8.44 & 32.05 & -- \\
\hline CT-159 & 7.15 & 6.20 & 6.20 & 7.47 & 8.99 & 36.15 & -- \\
\hline CT-185 & 8.22 & 7.19 & 7.19 & 8.60 & 9.46 & 38.57 & -- \\
\hline CT-210 & 7.41 & 8.08 & 8.08 & 8.25 & 8.86 & 38.82 & -- \\
\hline \multirow{2}{*}{$\begin{array}{l}\text { S-1635 } \\
\text { (Check) }\end{array}$} & 7.79 & 7.70 & 7.70 & 8.25 & 10.12 & 40.92 & -- \\
\hline & & & & $\begin{array}{r}\mathrm{CD} \text { at } 5 \% \\
\mathrm{CV} \%\end{array}$ & $\begin{array}{c}\text { Geno } \\
\text { Sea x Gen }\end{array}$ & $\begin{array}{l}1.81 * * \\
0.81 * * \\
11.00\end{array}$ & \\
\hline
\end{tabular}

Table 2. Leaf senescence (\%) of nine selected delayed senescent mulberry genotypes.

\begin{tabular}{|c|c|c|c|c|c|c|c|}
\hline \multirow{2}{*}{ Genotype } & \multicolumn{5}{|c|}{ Leaf senescence (\%) } & \multirow{2}{*}{ Mean } & \multirow{2}{*}{$\begin{array}{l}\text { Gain over } \\
\text { check (\%) }\end{array}$} \\
\hline & Sept & Nov & Feb. & Apr. & July & & \\
\hline CT-6 & 19.51 & 18.24 & 2.59 & 17.02 & 21.19 & 15.71 & 4.42 \\
\hline CT-11 & 23.33 & 19.07 & 2.11 & 16.78 & 22.44 & 16.75 & 3.38 \\
\hline CT-15 & 19.38 & 15.47 & 4.08 & 14.37 & 18.62 & 14.39 & 5.74 \\
\hline CT-44 & 12.38 & 13.06 & 0.55 & 6.84 & 16.19 & 9.80 & 10.33 \\
\hline CT-94 & 14.86 & 18.52 & 1.39 & 11.18 & 18.97 & 12.98 & 7.15 \\
\hline CT-159 & 20.71 & 16.17 & 0.97 & 14.64 & 20.04 & 14.51 & 5.62 \\
\hline CT-185 & 22.75 & 19.65 & 2.21 & 19.72 & 24.74 & 17.81 & 2.32 \\
\hline CT-210 & 21.74 & 18.70 & 2.62 & 19.43 & 20.40 & 16.58 & 3.55 \\
\hline \multirow{3}{*}{$\begin{array}{l}\text { S-1635 } \\
\text { (Check) }\end{array}$} & 23.67 & 24.98 & 6.15 & 19.53 & 26.34 & 20.13 & ---- \\
\hline & & & & CD at $5 \%$ & Geno & $1.08^{* *}$ & \\
\hline & & & & CV\% & & 17.17 & \\
\hline
\end{tabular}


higher in CT-44 than the same in all other genotypes including the check S-1635 (Table 3). The correlation coefficient between the important physiological and biochemical characters with leaf yield revealed that significantly positive relationships exist between leaf yield and photosynthetic rate, physiological water use efficiency and NRA activities (Table 4). The photosynthetic rate $\left(\mathrm{P}_{\mathrm{n}}\right)$ had significant positive correlation with $\mathrm{LY}$ (0.536), TSP (0.607), NRA (0.617) and pWUE (0.611). Similarly, NRA had strong positive association with $\mathrm{P}_{\mathrm{n}}$ (0.617), LY (0.613), TSS (0.260) and TSP (0.729). However, leaf senescence \% had significantly negative correlation with $\mathrm{P}_{\mathrm{n}}(-0.683)$, TSP $(-0.468)$ and NRA $(-0.335)$.

The results on path co-efficient analysis (Table 5) re- vealed that direct contributions of physio-biochemical characters on leaf yield ranged from 0.730 in LAI to -0.280 in ${ }_{p}$ WUE. The second highest direct effect on leaf yield was shown by TSP (0.449) followed by Pn (0.218) and LS (0.154). Although the LS had a non-significant negative correlation with leaf yield, it had a very low direct effect on leaf yield. However, it is likely to be contributing towards leaf yield, negatively, through Pn, TSP and LAI. Besides, positive correlations and direct negative effects on leaf yield were also found in the characters viz., NRA $(-0.177)$ and pWUE $(-0.280)$. But their indirect positive effect was through TSP and LAI. Non-significant negative correlation was seen in TSS with a low direct negative effect on leaf yield, but it had indirect positive effect through pWUE and LAI.

Table 3. Important physio-biochemical characters of nine selected delayed senescent mulberry genotypes.

\begin{tabular}{|c|c|c|c|c|c|}
\hline Genotype & $\begin{array}{c}\mathrm{Pn} \\
\left(\mu \mathrm{mol} \mathrm{m} \mathrm{m}^{-2} \cdot \mathrm{s}^{-1}\right)\end{array}$ & $\begin{array}{c}\text { pWUE } \\
\left(\mu \mathrm{mol} \mathrm{CO} \mathrm{mol}^{-1} \mathrm{H}_{2} \mathrm{O}\right)\end{array}$ & $\begin{array}{c}\text { TSS } \\
\left(\mathrm{mg} \cdot \mathrm{g}^{-1} \cdot \mathrm{fw}\right)\end{array}$ & $\begin{array}{c}\text { TSP } \\
\left(\mathrm{mg} \cdot \mathrm{g}^{-1} \cdot \mathrm{fw}\right)\end{array}$ & $\begin{array}{c}\text { NRA } \\
\left(\mu \mathrm{mol} \mathrm{NO} \mathrm{g}^{-1} \cdot \mathrm{fw}^{-1} \cdot \mathrm{h}^{-1}\right)\end{array}$ \\
\hline CT-6 & 6.24 & 0.61 & 21.34 & 28.07 & 5.58 \\
\hline СТ-9 & 7.17 & 1.13 & 23.91 & 27.70 & 9.34 \\
\hline CT-11 & 9.09 & 1.11 & 24.14 & 37.00 & 13.52 \\
\hline CT-15 & 8.99 & 0.87 & 23.47 & 36.03 & 12.42 \\
\hline CT-44 & 14.83 & 1.16 & 27.87 & 39.74 & 17.78 \\
\hline CT-94 & 8.62 & 0.74 & 21.04 & 28.87 & 10.60 \\
\hline CT-159 & 10.52 & 0.93 & 22.08 & 29.83 & 8.88 \\
\hline CT-185 & 6.20 & 0.81 & 22.18 & 26.21 & 12.00 \\
\hline CT-210 & 6.91 & 0.55 & 22.80 & 33.33 & 16.57 \\
\hline $\begin{array}{l}\text { S-1635 } \\
\text { (Check) }\end{array}$ & 9.92 & 1.28 & 22.62 & 28.82 & 12.21 \\
\hline CD at $5 \%$ & $1.18^{* *}$ & $0.14^{* *}$ & $2.73 * *$ & $3.40^{* *}$ & $2.79 * *$ \\
\hline CV\% & 8.38 & 8.75 & 7.18 & 6.76 & 9.93 \\
\hline
\end{tabular}

$\mathrm{P}_{\mathrm{n}}$-Net photosynthetic rate $\left(\mu \mathrm{mol} \mathrm{CO} 2 \mathrm{~m}^{-2} \cdot \mathrm{s}^{-1}\right)$; LY_Leaf yield $\left(\mathrm{kg} \cdot \mathrm{ha}^{-1} \cdot \mathrm{year}^{-1}\right)$; TSS—Total soluble sugar $\left(\mathrm{mg} \cdot \mathrm{g}^{-1} \cdot \mathrm{fw}\right) ; \mathrm{TSP}$ - Total soluble protein $\left(\mathrm{mg} \cdot \mathrm{g}^{-1}\right.$ $\mathrm{fw})$; NRA—Nitrate reductase activity $\left(\mu \mathrm{mol} \mathrm{NO} \mathrm{N}_{2}\right.$ formed $\left.\mathrm{g}^{-1} \cdot \mathrm{fw}^{-1} \mathrm{~h}^{-1}\right)$; pWUE—Physiological water use efficiency; LF—Leaf fall (\%); * and ** significant at $5 \%$ and $1 \%$ level, respectively.

Table 4. Correlations of physio-biochemical characters with leaf yield and leaf senescence (\%) among delayed senescent high yielding mulberry genotypes.

\begin{tabular}{cccccccc}
\hline Parameters & TSS & TSP & NRA & pWUE & LS & LAI & LY \\
\hline Pn & -0.169 & $0.625^{* *}$ & $0.617^{* *}$ & $0.661^{* *}$ & $-0.755^{* *}$ & $0.558^{* *}$ & $0.536^{* *}$ \\
TSS & & -0.076 & $0.292^{*}$ & $-0.477^{* *}$ & 0.159 & 0.246 & -0.025 \\
TSP & & & $0.780^{* *}$ & $0.527^{* *}$ & $-0.462^{* *}$ & $0.585^{* *}$ & $0.674^{* *}$ \\
NRA & & & 0.252 & $-0.438^{* *}$ & $0.699^{* *}$ & $0.610^{* *}$ \\
PWUE & & & & $-0.359^{* *}$ & $0.436^{* *}$ & $0.433^{* *}$ \\
LS & & & & & -0.221 & -0.239 \\
LAI & & & & & & & \\
\hline
\end{tabular}

Pn—Net photosynthetic rate $\left(\mu \mathrm{mol} \mathrm{CO} 2 \mathrm{~m}^{-2} \cdot \mathrm{s}^{-1}\right)$; LY—Leaf yield $\left(\mathrm{kg} \cdot \mathrm{ha}^{-1} \cdot \mathrm{year}^{-1}\right)$; TSS—Total soluble sugar (mg $\left.\cdot \mathrm{g}^{-1} \cdot \mathrm{fw}\right)$; TSP — Total soluble protein $\left(\mathrm{mg} \cdot \mathrm{g}^{-1}\right.$

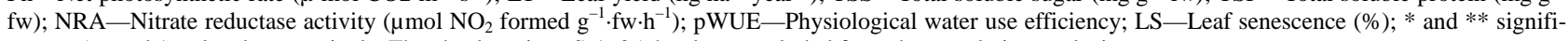
cant at 5\% and $1 \%$ level, respectively. The check variety, S-1635, has been excluded from the correlation analysis. 
Table 5. Direct and indirect path co-efficient values of important physio-biochemical characters of delayed senescent mulberry genotypes with leaf yield among delayed senescent high yielding mulberry genotypes.

\begin{tabular}{|c|c|c|c|c|c|c|c|c|}
\hline \multirow{2}{*}{ Path of } & \multicolumn{7}{|c|}{ Path through } & \multirow{2}{*}{ r with LY } \\
\hline & Pn & TSS & TSP & NRA & pWUE & LS & LAI & \\
\hline Pn & $\underline{0.218}$ & 0.041 & 0.281 & -0.109 & -0.185 & -0.116 & 0.407 & $0.536^{* *}$ \\
\hline TSS & -0.037 & $-\underline{0.240}$ & -0.034 & -0.052 & 0.134 & 0.024 & 0.180 & -0.025 \\
\hline TSP & 0.136 & 0.018 & $0 . \underline{449}$ & -0.138 & -0.148 & -0.071 & 0.427 & $0.674 * *$ \\
\hline NRA & 0.135 & -0.070 & 0.350 & $-\underline{0.177}$ & -0.071 & -0.067 & 0.511 & $0.610^{* *}$ \\
\hline PWUE & 0.144 & 0.114 & 0.236 & -0.045 & $-\underline{0.280}$ & -0.055 & 0.318 & $0.433^{* *}$ \\
\hline LS & -0.165 & -0.038 & -0.207 & 0.077 & 0.101 & $\underline{0.154}$ & -0.161 & -0.239 \\
\hline LAI & 0.122 & -0.059 & 0.262 & -0.123 & -0.122 & -0.034 & $\underline{0.730}$ & $0.776^{* *}$ \\
\hline
\end{tabular}

Underlined path co-efficient values are having direct effect on leaf yield; Pn—Net photosynthetic rate $\left(\mu \mathrm{mol} \mathrm{CO} 2 \mathrm{~m}^{-2} \cdot \mathrm{s}^{-1}\right)$; LY—Leaf yield $\left(\mathrm{kg}^{-1} \cdot \mathrm{ha}^{-1} \cdot \mathrm{year}^{-1}\right)$; TSS—Total soluble sugar $\left(\mathrm{mg}^{-1} \cdot \mathrm{g}^{-1} \cdot \mathrm{fw}\right)$; TSP-Total soluble protein $\left(\mathrm{mg} \cdot \mathrm{g}^{-1} \cdot \mathrm{fw}\right)$; NRA—Nitrate reductase activity $\left(\mu \mathrm{mol} \mathrm{NO}_{2}\right.$ formed $\left.\mathrm{g}^{-1} \cdot \mathrm{fw} \cdot \mathrm{h}^{-1}\right)$; $\mathrm{pWUE}-$ Physiological water use efficiency; LS-Leaf senescence (\%); * and ** significant at $5 \%$ and $1 \%$ level, respectively; Residual effect = 0.225 ; The check variety, S-1635, has been excluded from the path co-efficient analysis.

\section{DISCUSSION}

In India, the mulberry leaf production has increased considerably from $14 \mathrm{mt} / \mathrm{ha} / \mathrm{yr}$ in 1940 s to $75 \mathrm{mt} / \mathrm{ha} / \mathrm{yr}$ now [26]. This remarkable achievement is the result of intensive and systematic efforts of collection, characterization and utilization genetic resources for breeding. Large numbers of mulberry accessions have been maintained in all the major breeding Institutes of mulberry. For instance, Central Sericultural Germplasm Resources Centre (CSGRC), Hosur, the main germplasm bank, maintains a total of 1120 (856 indigenous and 264 exotic) accessions of mulberry [27], which are being used for systematic breeding. However, most the mulberry varieties which are being used for commercial silkworm rearing show high seasonal variations in the leaf yield, especially those being cultivated in the temperate and semitropical regions. This is because the ideal atmospheric temperature for mulberry growth is between $23.0^{\circ} \mathrm{C}-26.6^{\circ} \mathrm{C}$ and soil temperature is $25^{\circ} \mathrm{C}$ and if the atmospheric temperature goes below $25^{\circ} \mathrm{C}$ the growth of mulberry gets affected. When the temperature falls below $13^{\circ} \mathrm{C}$ the growth stops and the plant enters into a period of dormancy. Similarly, when the available soil moisture reduces by one third of the field capacity, growth gets affected and the moisture reduced by two third of the field capacity, the growth stops completely [28]. Thus, the leaf production during cold months falls drastically leaving a big gap between the availability and demand for leaf. For instance, the leaf yield of S1635 in West Bengal during the five silkworm crop is $2989 \mathrm{~kg} / \mathrm{ha}$ (February), 4643 kg/ha (April), 5960 kg/ha (July), 5815 $\mathrm{kg} / \mathrm{ha}$ (September) and $3434 \mathrm{~kg} / \mathrm{ha}$ (November) [2]. Although, no variety was developed in India to solve this problem, attempts in China and Russia have resulted in developing cold hardy mulberry varieties. Varieties like Zimestojkij and Ukranin-1 are known to be cold tolerant
$[29,30]$. Similarly, research in other crops revealed the possibility of developing cold hardy mulberry varieties if adequate attention is taken for screening of germplasm banks to identify potential parents, hybridization of desired parents, screening and selection of progenies and evaluation and identification of the varieties having high leaf yield potential and stability across seasons.

Regarding the character association for cold hardiness, it has been found that a strong positive correlation exists between the rate of photosynthesis and cold hardiness. Normally, photosynthesis during the winter season is limited by unfavorable environmental conditions [31]. Seasonal changes in the rate of photosynthetic capacity were also observed as the photosynthesis increases in spring and decreases in autumn [32]. In the present study, the photosynthesis of CT-44 was much higher than that in any other genotypes during the colder months. This clearly indicates the innate ability (genetic potentiality) of this genotype to tolerate cold much better than other genotypes. Earlier, reference [11] reported that cold resistant varieties of wheat exhibited higher photosynthetic rate. There was also positive correlation between photosysnthesis with leaf yield. Similarly, nitrate reductase activity was also higher in CT-44, which was in corroboration with the earlier observation that cold resistant genotypes have higher nitrate reductase activity [33]. Maize seedling that developed under low temperature was found having low pigments [34], changed antioxidative defense [35]. These changes probably reflect the ability of the plant to adjust to the varying climatic conditions. In the present work it could be seen that leaf yield and photosysnthesis was positively and signifycantly correlated. Thus, under cold seasons CT-44 yielded much higher than others and the leaf senescence was much less (9.80\%). Thus, there is a negatively signifycant correlation between leaf senescence and the leaf yield. Plants with delayed leaf senescence were found 
yield substantially higher during colder months [14]. The significant correlation between leaf yield and other important physiological and biochemical traits viz., $\mathrm{P}_{\mathrm{n}}$, TSP, NRA and LAI, suggests the possibility of using these parameters for selection of mulberry genotypes for better leaf yield under cold conditions. Therefore, in mulberry, genotypes with delayed leaf senescence have higher LAI, TSP, $\mathrm{P}_{\mathrm{n}}$ and NRA activity, which in turn lead to higher leaf yield. Thus, leaf senescence can be considered as important selection criteria. The character association and path coefficient analysis further support this fact.

Thus, CT-44, developed in this study has better cold tolerance, which is clearly evidenced from the higher leaf yield over the check (S-1635) during all the silkworm seasons. It can be further concluded that, for sustainable bivoltine sericulture in West Bengal, CT-44 can be of much use and the important physio-biochemical characters viz., high $\mathrm{P}_{\mathrm{n}}$, TSP, NRA and LAI will be of worthy to consider for the development of mulberry varieties with delayed leaf senescence during colder months and to provide consistently higher leaf yield irrespective of the seasonal changes.

\section{REFERENCES}

[1] Dutta, R.K. and Nanavaty, M. (2005) Global silk industry-A complete source book. Universal Publishers, Pompano Beach.

[2] Vijayan, K., Chakraborti, S.P., Roy, B.N. and Sen, S.K. (1998) Winter hardy mulberry varieties: A need. Indian Silk, 37, 6-8

[3] Rahman, M.S., Doss, S.G., Debnath, S., Roy-Chowdhuri, S., Ghosh, P.L. and Sarkar, A. (2006) Genetic variability and correlation studies of leaf characters in some mulberry (Morus spp.) germplasm accessions. Indian Journal of Genetics and Plant Breeding, 66, 359-360.

[4] Pandit, D., Ghosh, S. and Das, N.K. (2005) Factors influencing sericultural productivity-An analysis in trational areas of West Bengal. Journal of Interacademicia, 9, 281-291.

[5] Fowler, S. and Thomashow, M.F. (2002) Arabidopsis transcriptome profiling indicates that multiple regulatory pathways are activated during cold acclimation in addition to the CBF cold response pathway. Plant Cell, 14, 1675-1690. doi:10.1105/tpc.003483

[6] Xiao, H., Siddiqua, M., Braybrook, S. and Nassuth, A. (2006) Three grape CBF/DREB1 genes respond to low temperature, drought and abscisic acid. Plant Cell and Environment, 29, 1410-1421. doi:10.1111/j.1365-3040.2006.01524.X

[7] Nanjo, T., Kobayashi, M., Yoshida, Y., Kakubari, Y., Yamaguchi-Shinozaki. K. and Shinozaki, K. (1999) Antisense suppression of proline degradation improves tolerance to freezing and Salinity in Arabidopsis thaliana. FEBS Letters, 461, 205-210. doi:10.1016/S0014-5793(99)01451-9

[8] Sakai, A. and Larcher, W. (1987) Frost survival of plants: Response and adaptation to freezing stress. In: Billings,
W.D., Golley, F., Lange, O.L., Olson, J.S. and Remmert, H., Eds., Springer, Berlin, 303-326.

[9] Repo, T. (1992) Seasonal changes of frost hardiness in Picea abies and Pinus sylvestris in Finland. Canadian Journal of Forestry Research, 22, 1949-1957. doi:10.1139/x92-254

[10] Beck, E., Hansen, J., Heim, R., Schäfer, C., Vogg, G., Leborgne, N., Teulieres, C. and Boudet, A.M. (1995) Cold hardening and dehardening of evergreen trees. In: Sandermann, H. and Bonnet-Masimbert, M., Eds., INRA Edition, 76, 171-193.

[11] Puzakova, A.A. and Koshova, N.J. (1980) Correlation of physiological and biochemical process during cold hardening and overwintering in wheat. Fiziologiya I Biokhimiya Kulturnykh Rastenii, 12, 458-462.

[12] Guo, Q. and Pan, C.C. (1984) Effect of ABA on resistance of rice seedlings to chilling injury. Acta Phytophysiologica Sinica, 10, 295-303.

[13] Mc Murphy, L.M. and Rayburn, A.L. (1992) Chromosomal and cell size analysis of cold tolerant maize. Theoretical and Applied Genetics, 84, 798-802. doi:10.1007/BF00227387

[14] Rivero, R.M., Kojima, M., Gepstein, A., Sakakibara, H., Mittler, R., Gepstein, S. and Blumwald, E. (2007) Delayed senescence induces extremen drought tolerance in a flowering plant. Proceedings of National Academy of Sciences, 104, 19631-19636. doi:10.1073/pnas.0709453104

[15] Banerjee, R., Roychowdhuri, S., Sau, H., Das, B.K., Ghosh, P. and Saratchandra, B. (2007) Genetic diversity and interrelationship among mulberry genotypes. Journal of Genetics and Genomics, 34, 691-697. doi:10.1016/S1673-8527(07)60078-2

[16] Das, C, Sahu, P.K., Sengupta, T., Misra, A.K., Saratchandra, B. and Sen, S.K. (2001) Genetic variability in some physiological traits in mulberry. Indian Journal of Plant Physiology, 6, 162-165.

[17] Tikader, A., Vijayan, K., Raghunath, M.K., Chakraborti, S.P., Roy, B.N. and Pavankumar, T. (1995) Studies on sexual variations in mulberry (Morus spp). Euphytica, 84, 115-120. doi:10.1007/BF01677948

[18] Vijayan, K., Das, K.K., Doss, S.G., Chakraborti, S.P. and Roy, B.N. (1999) Genetic divergence in indigenous mulberry. Indian Journal of Agricultural Sciences, 69, 851853.

[19] Vijayan, K., Chakraborti, S.P. and Ghosh, P.D. (2004) Screening of Mulberry (Morus spp.) for salinity tolerance through in vitro seed germination. Indian Journal of Biotechnology, 3, 47-51.

[20] Vijayan, K., Doss, S.G., Chakraborti, S.P. and Ghosh, P.D. (2009) Breeding for salinity resistance in mulberry (Morus spp.). Euphytica, 169, 403-411. doi:10.1007/s10681-009-9972-x

[21] Ray, D., Mondal, L.N., Pain, A.K. and Mondal, S. (1973) Effect of NPK and farm yard manure on the yield and nutritive values of mulberry leaf. Indian Journal of Sericulture, 12, 7-12

[22] Yemm, E. and Willis, A.J. (1954) The estimation of carbohydrate in plant extracts by Anthrone. Biochemical Journal, 57, 508-514.

[23] Lowry, O.H., Rosebrough, N.J., Farr, A.L. and Randall, R.J. (1951) Protein measurements with folin-phenol re- 
agent. Journal of Biological Chemistry, 193, 265-275.

[24] Jaworski, E.G. (1971) Nitrate reductase assay in intact plant tissues. Biochemistry and Biophysics Research Communications, 43, 1274-1279. doi:10.1016/S0006-291X(71)80010-4

[25] Paliwal, K. and Ilangovan, M. (1990) Factors influencing in vivo determination of nitrate reductase (E.C.1.6.6.1.) activity in mulberry (Morus alba L.). Sericologia, 30, 369-379.

[26] Saratchandra, B., Vijayan, K., Srivastava, P.P. and JayaramaRaju, P. (2011) Three new authorized mulberry varieties. Indian Silk, 2, 14-15.

[27] Vijayan, K., Saratchandra, B. and da Silva, J.A.T. (2011) Germplasm conservation in mulberry. Scientia Horticulturae, 128, 371-379. doi:10.1016/j.scienta.2010.11.012

[28] Ohyama, K. (1966) Effect of soil moisture on growth of mulberry tree. Bulletin of the Sericultural Experiment Station, 20, 333-359.

[29] Filippovich, J.B. and Stasanova, M.I. (1965) Relationship between frost resistance of mulberry and water metabolism. Shelk, 2, 7-8.

[30] Pryluckyi, O.V. (1969) Study of metabolism in mulberry varieties of different winter hardiness. Sovkivn Mizrid Nauk Zvrm, 5, 59-64.

[31] Ensminger, I., Sveshnikov, D., Campbell, D.A., Funk, C.,
Jansson, S., Lloyd, J., Shibistova, O. and O"quist, G. (2004) Intermittent low temperatures constrain spring recovery of photosynthesis in boreal Scots pine forests. Global Change in Biology, 10, 995-1008. doi:10.1111/j.1365-2486.2004.00781.x

[32] Nilsson, J.E. (2001) Seasonal changes in phenological traits and cold hardiness of F1-populations from plustrees of Pinus sylvestris and Pinus contorta of various geographical origins. Scandinavian Journal of Forest Research, 16, 7-20. doi:10.1080/028275801300004361

[33] Zhao, M.G., Chen, L., Zhang, L.L. and Zhang, W.H. (2009) Nitric reductase-dependent nitric oxide production is involved in cold acclimation and freezing tolerance in Arabidopsis. Plant Physiology, 151, 755-767. doi:10.1104/pp.109.140996

[34] Haldimann, P., Frachebound, Y. and Stamp, P. (1995) Carontenoid composition in Zea mays developed at suboptimal temperature and different light intensities. Physiologia Plantarum, 95, 409-414. doi:10.1111/j.1399-3054.1995.tb00856.x

[35] Kingston-Smith, A.H., Harbinson, J. and Foyer, C.H. (1999) Aclimation of photosysnthesis, $\mathrm{H}_{2} \mathrm{O}_{2}$ content and antioxidents in maize (Zea mays) grown in suboptimal temperatures. Plant Cell and Environment, 22, 1071-1083. doi:10.1046/j.1365-3040.1999.00469.x 